УДК 316.013.37

Received 21 September 2017

Received in revised form 25 October 2017

Accepted 23 November 2017

\section{СОЦАЛЬНІ НАУКИ}

Комих Н.Г.,

Дніпровський національний університет імені Олеся Гончара e-mail:kom-nata@i.ua

\title{
АКТУАЛЬНІ ЕКОЛОГІЧНІ ПРАКТИКИ ІНДИВІДА В МІСЬКОМУ СЕРЕДОВИЩІ: СОЦІОЛОГІЧНА ІНТЕРПРЕТАЦІЯ
}

Резюме. Статтю присвячено сочіологічному аналізу екологічних практик, в рамках теоретичних положень структуралістко-конструктивістського підходу, на прикладі дослідження суспільної думки мешканців міста Дніпро.

Ключові слова: екологічні практики, міське середовище, м. Дніпро.

Комых Н.Г., Днипровский национальный университет имени Олеся Гончара, e-таil: kom-nata@i.ua

Актуальные экологические практики индивида в городской среде: социологическая интерпретация.

Резюме. Статья посвящена сочиологическому анализу экологических практик, в рамках теоретических положений структуралистко-конструктивистского подхода на примере исследования общественного мнения жителей города Днипро.

Ключевые слова: экологические практики, городская среда, г. Днипро.

Komyh N.G., Oles Honchar Dnipro National University, e-mail: kom-nata@i.ua

Actual environmental practies of in an Urban environment: sociological interpretation.

Abstract. The article is devoted to the sociological analysis of environmental practices in the framework of the theoretical positions of structuralist-constructivism, on the example of the public opinion survey of residents of the Dnipro population.

Keywords: environmental practies, Urban environment, Dnipro.

В епоху глобалізації, зміни у різноманітних просторах соціальної реалності $\epsilon$ незворотніми. Відбувається актуалізація для наукового вивчення, зокрема й соціологічного аналізу, цілої низки соціальних проблем у розвитку людства, серед яких генеральною $\epsilon$ екологічна. Глобальні кризи на початку XXI ст. (фінансово-економічна, енергетична, продовольча, продовольча), масова міграція, падіння народжуваності в Європі, зростання невизначеності, невпевненості, конфліктогенності тощо справді змушують інтелектуалів замислитись над природою кризових явищ і пріоритетами подальшого розвитку людства. Для того, щоб забезпечити безпеку людства у майбутньому, далекоглядні експерти пропонують відмовитись від принципу антропоцентризму, згідно 3 яким “людина є мірою всіх речей”, на користь збалансованого екоцентризму. У зв'язку 3 цим, потрібно обмежити споживання, засмічення навколишнього середовища, скоротити шкідливе виробництво, дбайливо ставитись до природи. На жаль, ця пропозиція залишається практично утопією, бо у світі, навпаки, спостерігається посилення конкуренції за природні ресурси, зростає економічна напруга, мають місце гострі політичні конфлікти. Зазаначені проблеми $\epsilon$ макрорівневі. На мезо- та мікрорівні соціологічного аналізу можливості подолання зазаначених екологічних загроз, ідеології 
антропоцентризму полягає в дослідженні розповсюдження та інституційного закріплення екологічних практик в повсякденності індивіда.

Рамках структуралістського конструктивізму конкретизуються теоретичні аспекти дослідження соціальних практик на мезорівневому аналізі. Структури детермінують практики за П. Бергером, Т. Лукманом. А от П. Бурдьє, Е. Гідденс, вважали, що аналіз взаємодії індивідів $є$ дуже складним та потребує синтезу 3 макротеоретичним досвідом. Структуралістський конструктивізм припускає розгляд соціальної дійсності 3 позицій структуралізму, а саме подвійного структурування, де в соціальній системі існують об'єктивні структури, незалежні від свідомості і волі людей і самі структури, які створюються соціальнимипрактиками агентів. I другий принцип конструктивізм, згідно якому дії людей формуються в результаті процесу соціалізації, накопичення життєво досвіду, схильністю діяти різноманітно залежно від ситуації, що і є матрицями соціальної дії, які дозволяють агентові конструювати об'єкти. В якості структуруючої структури практики агентів виступає на думку вченого - габітус.

У вітчизняній соціології, в контексті зазначенного нами напрямку дослідження, приділяє увагу теорії практик та ролі практик у стратифікаційному порядку Н.Коваліско [3, с. 49-63]. Дослідниця зазначає, що перехідних суспільствах, яким є українське, відбувається поступоватрансформаціяцінніснихорієнтацій особистості, щопризводить до змін соціальних практик, соціальних потреб індивіда, та їх інституалізації. Отже, індивід орієнтується в соціальному просторі та здійснює свій вибір соціальних практик в залежності від певної структури особистості. Зазаначений механізм подвійного структурування обраний нами як методологічна основа для розгляду екологічних прктику.

Мета статті полягає успробі на основі застосування структуралісткоконструктивістського підходу та інтерпретації результатів соціологічного дослідження зхарактеризувати види екологічних практик мешканців міста Дніпро розповсюдженні в їх повсякденному просторі.

Для реалізації поставленої мети, зазначимо ключові положення теорії соціальних практик, що $\epsilon$ каркасом подальшого глибинного аналізу. Практика виступає предметом ретельного, скрупульозного аналізу в працях французького соціолога П. Бурдьє. Домінуючю роль у розумінні механізму здійсненя певних соціальних практик вчений пов'язує 3 поняттям габітус. Реалізація практики можлива за умови інтеріоризації соціальних структур агентами. П. Бурдьє вводить категорію габітусу як системи стійких диспозицій індивіда, структуруючі структури. Які дозволяють індивіду орієнтувіатися в соціальному просторі та здійснювати певні практики. Габітус виступає продуктом історії, це набута система породження практичних схем. Зрозуміти, що є габітус можна тільки за умови співвіднесення соціальних умов, в яких він формувався, з соціальними умовами, в яких він був приведений в дію, т. п. провести наукову роботу по встановленню зв'язку між двома станами соціального світу, які реалізуються габітусом, що встановлює цей зв'язок за допомогою практики і в практиці. Габітус - це і умова, і принцип реалізації практик. Соціологічний вимір габітусу неможливо, він проявляється через практики агентів [1, с.102].

Нібито доповнює та поглиблює дискурс соціальних практик в соціології концепція Е. Гідденс. Англійський соціолог пропонує розглядати соціальну реальність крізь призму відтворюючихся соціальних практик. «Система - вибудовування за певним зразком через простір і час соціальних відносин, що розуміються як відтворювані практики» $[3$, с. 501].

Соціальна практика не створюється соціальними акторами, а лише постійно відтворюється ними, тобто, практика має такі властивості, як впорядкованість i спадкоємність. Відтворення, рутинізація соціальних практик свідчать про стабільність 
самої соціального життя. В цілому Е. Гідденс визначає соціальне життя як сукупність соціальних практик, тим самим намагаючись подолати протиставлення макро- i мікросоціологічного рівнів. На елементарному рівні практика являє собою безперервність існування індивідуумів в конкретних контекстах. Велика частина життєдіяльності людей складається зі звичних дій, рутинний характер яких дозволяє пояснити практичну природу соціальних структур. Впорядкованість практик $є$ іманентною: вона породжується не включенностью людського діï в макросоціальних порядок, а його рутинізацією в середовищі повсякденності завдяки схемам практичного свідомості. Таким чином, Е. Гідденс принципово відмовляється від ідеї припущеного макросоціального інституційного порядку i намагається теоретично реконструювати виробництво i відтворення множинних порядків соціальними практиками в середовищі повсякденності. Цілісна послідовність соціальних практик передбачає рефлексивність, яка, на думку Е. Гідденса, можлива лише в умовах послідовної безперервності цих практик, що дозволяє сприймати їх чітко тотожними один одному в часі і просторі. Онтологія простору-часу - невід'ємний утворює елемент соціальних практик по Е. Гидденсу.

Отже, в сучасному суспільстві традиційні, типові, стереотипні форми соціальних практик видозмінюються, наповнюються новим змістом. Спектр соціально-культурних практик розширюється, i вони стають максимально розвиваючими людський потенціал формами життєдіяльності людей.

Певний тип екологічних практик відповідає історичному етапу розвитку соціальноекономіних відносин. На ранніх етапах цивілізаційного розвитку існувала натуральна господарська діяльність, що не представляє глобальних загроз для навколишнього середовища. 3 розвитком цивілізації економіка трансформується та виробляє екологічні практики, що стають вирішальними у відтворенні певного соціального порядку, деконструкції соціального простору.
На сучасному етапі розвитку ци значимим макроконнтекстом $є$ процеси глобалізації, урбанізації. В умовах глобалізації виживання людства як єдиного цілого i подолання екологічних викликів стає найбільш актуальним. Сучасні соціальні екологічні практики дозволяють сконструювати нові структури, що сприяють екологічній модернізації суспільства, де знання будуть узгоджуватися 3 стійкими моральними нормами, де буде можливо вирішення всього комплексу проблем навколишнього середовища.

Екологічна практика не відбувається абсолютно відокремлено від діяльності людини по перетворенню соціального середовища. На всіх етапах людської історії ці два види діяльності виявляються вплетеними один в одного, внаслідок чого, соціально-екологічні відносини можуть розглядатися як екологічний аспект всієї системи суспільних відносин - як відносин матеріальних (технологічних і економічних), так і вторинних, ідеологічних (політичних, правових, моральних і т. д.).

Характер та зміст екологічних практик залежить від типу поселення, а саме: сільського та міського. Міські екологічні практики спрямовані на безпечне облаштування навколишнього середовища існування людини. Екологічні практики спрямовані на подолання загроз для індивіда пов'язаних із забрудненням повітря, води, харчовою кризою, надлишковим сміттям та його утилізацією, розповсюдженням хвороби та інфексій. Найбільш розповсюдженними різновидами екологічних практик є: прибирання сміття, його утилізація, вживання екологічної їжі, води, профілактика захворювань, здоровий спосіб життя, екологчне просвітництво.

Екологічні практики сільських поселень багато в чому відрізняються від міських, але, тим не менш, вони відіграють велику роль в екологічній трансформації суспільства, так як відзеркалюють гармонію між середовищем проживання, діяльністю і суб'єктами 
діяльності. Форми екологічних практик сільських поселень: виробництво екологічно чистих продуктів харчування, виробництво товарів і послуг для здорового способу життя, задоволення рекреаційних потреб суспільства, створення екологічних поселень.

Важливо, що у зазначених екологічних практиках ми акцентуємо увагу на взаємодії людини та навколишнього середовища на рівні мікроаналізу. Пошуку їх гармонійної взаємодії. Міста $є$ простором побудови комфортних та коеволюційних стосунків людей та природи. Експерти, представники різноманітних наукових напрямів визнають, що майбутне людства пов'язано $з$ містами. Зараз існує близько сотні міст-міліонерів, а ще двісті років назад був один - Лондон. Організація міського способу життя потребує збільшення споживання, просторової організації, облаштування екологічного навколишнього середовища.

Місто - $є$ епіцентром сучасності, де відбувається наповнення життєвих історій містян; зосереджено різноманітні форми соціальної комунікації, де взаємодіють публічні та приватні простори i все це підкоряється часу, який формує єдиний стрімкий ритм повсякденних режимів транспортного, інформаційного, політичного, індустріального, культурного. Екологічний стан міського середовища безпосередньо визначає якість життя і здоров'я людини. Для зосередження уваги на структурі мезосередовища розгортання екологічних практик, застосуємо теоретичний конструкт «екологічне місто».

Екологічне місто в рамках зазначеного дослідницького напряму, ми будемо розуміти як соціальний конструкт, який набуває своїх означень за певної оціночної характеристики його суб'єктів, має просторові (територіальні) ресурси, властивості. Наприкладі міста Дніпро, спробуємо визначити наскільки воно екологічне, придатне для безпечного проживання людей та вдало поєднує природне та штучне середовище існування людини.

Отже, маємо теоретико - методологічне підгрунття розглядати сучасне екологічне місто як певний простір, наповнений диспозиційними (кожен індивід має певну ієрархію позицій у полі простору - габітус), соціокультурними, інформаційними, комунікативними, фізичними характеристиками, що відтворюються, структуруються та підтримуються повсякденними практиками індивідів в рамках певних полей, в залежності від домінування форм капіталу.

Алгоритм дослідження детальної картини екологічного міста полягає в розгляді об'єктивних ресурсів території, т.п. екологічних показників, за якими можна визначити стан екології у місті: рівень забруднення повітря, доступність і чистота води, ретельність прибирання сміття, стан каналізаційних мереж. Характеристика базового ресурсу території надає можливість зафіксувати певні соціально-екологічні практики, які відтворюють екологічний простір міста. Для повної об' єктивної картини важливим доповненням $\epsilon$ дослідження суспільної думки населення міста спрямоване на аналіз екологічних проблем, екологічнх практик та уявлень про ідеальне екологічне місто мешканцями. Зосередемо увагу на аналізі суспільної думки мешканців м.Дніпро.

В Україні склалась вкрай загрозлива екологічна ситуація. Внаслідок безвідповідального господарювання, нераціонального використання природних ресурсів, перенасичення водних і земельних ресурсів залишками та відходами хімічного, металургійного, гірничорудного і т.п. виробництва, особливо радіоактивними викидами Чорнобильської $\mathrm{AC}$, Україна перетворилась в одну 3 екологічно найбрудніших країн європейського простору. Без нагальних екологозабезпечуючих змін, спрямованих на радикальне оздоровлення природи i суспільства, підвищення та формування екологічної культури, відвернути екологічну катастрофу, здається, майже неможливо. Неефективна в екологічному відношенні політика держави та система 
«Філософія та політологія в контексті сучасної культури», 2018, Т.10. №1-2 (22)

виробництва у поєднанні з нерозвиненістю інших соціальних інститутів та економізацією суспільного життя сприяють поступовій девальвації екологічних цінностей заниженню у свідомості громадян реальної вартості ресурсів природного середовища. Всі ці явища - недоліки механізмів нормативноправового й економічного регулювання, низького рівня екологічної свідомості та екологічної культури населення, недостатньої поінформованість громадян про стан довкілля, ïx необізнаність 3 власними екологічними правами, а також певна стурбованість окремих соціальних груп станом навколишнього середовища, підтверджують існування в сучасному українському суспільстві проблемної ситуації та її актуальністі.

Значним доповненням характеристики екологічного простору навколишнього середовища міста Дніпра є уявлення містян стосовно його екологічного стану. Думки та обізнаність громади міста стосовно екологічних проблем, шляхів їх вирішення та, головне, їх власні екологічні практики, ми маємо можливість проаналізувати за результатами соціологічного дослідження, методом опитування (інтернет анкетування), проведеного кафедрою соціології ДНУ ім. О.Гончара в березні 2018року. Цільова аудиторія дослідження - мешканці міста Дніпро віком від 18 років, які обрані за спеціальною процедурою.

Соціологічне дослідження показало, що екологічний стан довкілля $є$ важливою складовою у формуванні комфортної зони проживання для мешканців в місті. Як 3'ясувалось, за результатами дослідження екологічні проблеми дуже важливі та значимі для $-66,5 \%$ опитаних. Більшу стурбованість викликає тільки проблема зростання тарифів на комунальні послуги - 75\% респондентів. Подальший аналіз показав, що серед існуючих екологічних проблем у місті лідерами є: забруднення водоймів - 89\%; забруднення атмосферного повітря - 84\%; погіршення якості питної води -80\%; стан сміттєзвалищ -
$79 \%$ (див. табл.1).

Серед не значимих проблем міста помітно виділяється проблема підвищення захворюваності людей під впливом екологічних чинників - 7,8\% опитаних. Однак і стурбованість цією проблемою достатньо висока серед респондентів - 74,4\%.

Важливою складовою престижності району проживання $\epsilon$ екологічний чинник. $69 \%$ містян саме так вважають. Це не найбільш значимий фактор для містян. Вочевидь, проблематику обрання району проживання та їх престижності, слід вивчати більш тонкими методиками за якісними стратегіями соціологічного дослідження, так як часто при обранні району проживання спрацьовують як ситуативні фактори, так і об'єктивні.

На фоні загальної стурбованості мешканців міста екологічними проблемами міського довкілля важливим є питання реальної участі громадян у екологічних заходах, як значимої діяльнісної складової екологічної культури особистості (див. рис 1).

Як показано на рисунку 1, найбільш розповсюдженими практиками мешканців міста $є$ споживати очищену воду (51\%), економити воду (53\%), сортували сміття (46 \%). За позицією «економили електроенергію» вибір респондентів склав $21 \%$. У всіх інших заходах громадяни практично не приймають участь. Отримані дані свідчать про низький рівень екологічної активності мешканців міста.

\section{Екологічні практики городян (\% )}

Складається парадоксальна ситуація: містяни розуміють, що екологічний стан навколишнього середовища жахливий, але активіської позицій у діяльності по його покращенню не займають, натомість, всю 4відповідальність за ситуація, що склалась та важелі вирішення екологічних негараздів, покладають на міську владу та керівників промислових підприємств, природоохоронні установи, і тільки на останньому місці на особисту діяльність, мешканців міста та громадські організації. 


\section{Таблиця 1}

Рейтинг екологічних проблем, які більше всього турбують мешканців міста, (\%)

\begin{tabular}{|c|c|c|c|c|}
\hline & & 总 & 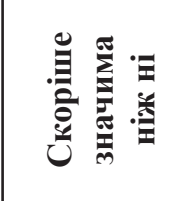 & 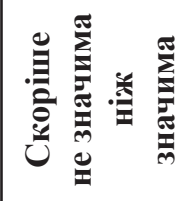 \\
\hline 1 & $\begin{array}{l}\text { Забруднення води в річках (ставках, водосховищах) } \\
\text { міста }\end{array}$ & 89,5 & 5,8 & 0,6 \\
\hline 2 & Забруднення атмосферного повітря & 84 & 11,6 & 1,3 \\
\hline 3 & Погіршення якості питної води & 80 & 12,7 & 1,9 \\
\hline 4 & Санітарний стан сміттєвих звалищ & 79 & 13,7 & 3,4 \\
\hline 5 & $\begin{array}{l}\text { Безгосподарське ставлення до відходів, їх } \\
\text { нераціональний збір }\end{array}$ & 77 & 16,6 & 2,3 \\
\hline 6 & $\begin{array}{l}\text { Підвищення захворюваності людей під впливом } \\
\text { екологічних чинників }\end{array}$ & 74,4 & 12,4 & 7,8 \\
\hline 7 & Сміття та бруд на вулицях міста & 71,7 & 20,4 & 4,4 \\
\hline 8 & Стан каналізаційних мереж міста & 69 & 19,6 & 1,2 \\
\hline 9 & Якість продуктів харчування & 56 & 28,2 & 2,3 \\
\hline 10 & $\begin{array}{l}\text { Погіршення санітарної ситуації в комунальних } \\
\text { закладах (лікарні, школи, дит.садки) }\end{array}$ & 54,6 & 25,7 & 3,3 \\
\hline
\end{tabular}

\section{Рисунок 1}

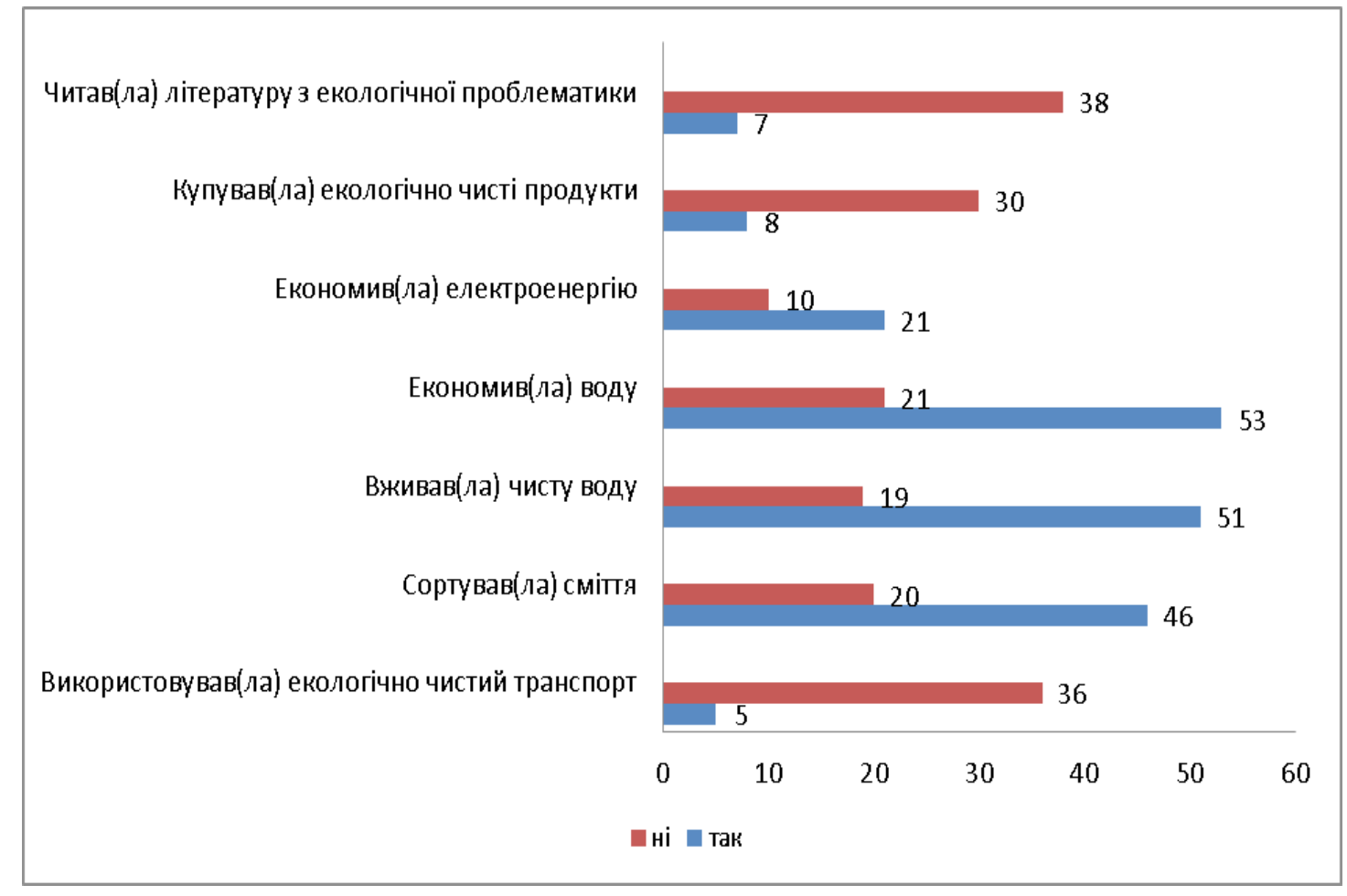




\section{Бібліографічні посилання}

1.Бурдье П. Практический смысл. /пер. с фр.: А. Т. Бикбов, К. Д. Вознесенская, С. Н. Зенкин, Н. А. Шматко. /отв. ред. пер. и послесл. Н. А. Шматко. СПб., 2001. 562 с.

2.Гидденс Э. Устроение общества: Очерк теории структурации. М., 2003. 528c.

3. Коваліско Н. Теорія практик в дослідженні стратифікаційного порядку. Социология: теория, методы, маркетинг. 2010. № 2. С. 49-63.

\section{References}

1.Burde P. Prakticheskij smysl. /per. s fr.: A. T. Bikbov, K. D. Voznesenskaya, S. N. Zenkin, N. A. Shmatko. /otv. red. per. i poslesl. N. A. Shmatko. SPb., 2001. 562 s.

2.Giddens E. Ustroenie obshestva: Ocherk teorii strukturacii. M., 2003. 528s.

3.Kovalisko N. Teoriya praktik v doslidzhenni stratifikacijnogo poryadku. Sociologiya: teoriya, metody, marketing. 2010. № 2. S. 49-63. 